\title{
Вплив нормобаричної гіперкапнічної гіпоксії на показники зовнішнього дихання осіб молодого віку, хворих на нейроциркуляторну дистонію
}

\author{
Удк 612.2-053.67:615.8
}

\author{
Ю. М. Фурман, В. Є. Онищук, Т. В. Дьомкіна
}

Вінницький державний педагогічний університет імені М. Коцюбинського, Вінниця, Україна

\begin{abstract}
Резюме. Мета. Науково-методично обґрунтувати та розробити програми фізичної реабілітації осіб молодого віку, хворих на нейроциркуляторну дистонію.

Методи. Теоретичний аналіз і узагальнення літературних джерел з теми наукового дослідження, електронна спірографія з аналізом петлі «потік-об'єм», методи математичної статистики

Результати. Заняття за розробленою програмою, яка включала методику створення в організмі стану нормобаричної гіперкапнічної гіпоксії, одномоментне обливання холодною водою після теплого душу, дозовані ходьбу та біг, вправи з використанням фітболів, ранкову гігієнічну гімнастику та аутогенне тренування за методикою Шульца, самомасаж викликали вірогідне покращення об'ємних показників зовнішнього дихання незалежно від типу захворювання в основних групах. На відміну від представниць основних груп, заняття за типовою програмою спеціальних медичних груп, які проводили в контрольних групах,суттєво не вплинули на показники зовнішнього дихання. Через 24 тиж. занять результати досліджень пропускної спроможності бронхів різного діаметра свідчать про те, що застосування в заняттях методики нормобаричної-гіперкапнічної гіпоксії позитивно відобразилось на тих швидкісних показниках зовнішнього дихання, які відображають здатність бронхів пропускати повітря в фазу видиху - ФЖЄЛ, ОФВ, , ПОШ, МОШ ${ }_{25}, \mathrm{MOШ}_{50}, \mathrm{MOШ}_{75}, \mathrm{COШ}_{25-75,} \mathrm{CO}_{75-85 .} \mathrm{y}$ дівчат контрольної групи заняття за типовою програмою з лікувальної фізичної культури для студенток з НЦД не викликали вірогідних змін цих показників.

Висновки. Узагальнення науково-методичної інформації свідчить про щорічну динаміку поширеності нейроциркуляторної дистонії серед осіб молодого віку. Результати дослідження показали, що застосування запропонованої комплексної програми, яка включає лікувальну гімнастику методику створення в організмі стану нормобаричної гіперкапнічної гіпоксії, ранкову гігієнічну гімнастику, одномоментне обливання холодною водою після теплого душу, самомасаж комірцевої зони та аутогенне тренування за методикою Шульца, сприяє покращенню середніх величин як зовнішніх, так і швидкісних показників зовнішнього дихання. Ключові слова: молодь, фізична реабілітація, вегето-судинна дистонія.
\end{abstract}

Impact of normobaric hypercapnic hypoxia on external respiration index of young patients with neurocirculatory dystonia

\section{Y. M. Furman, V. J. Onishchuk, T. V. Diomkina}

M. Kotsyubinsky Vinnytsia State Pedagogical University

Abstract. Objective. Scientifically and methodologically substantiate and develop physical rehabilitation programs for young people with neurocirculatory dystonia.

Methods. Theoretical analysis and generalization of literature on the topic of scientific research, electronic spirography with the analysis of the loop «flow volume», methods of mathematical statistics.

Results. Classes according to the developed program, which included the method of creating normobaric hypercapnic hypoxia in the body, single-cold pouring cold water after a warm shower, dosed walking and jogging, exercises with the use of fitballs, morning hygienic gymnastics and 
autogenous training according to Schults method, self-massage induced an increase in volume indices of external respiration, regardless of the type of disease in the main groups. Unlike the representatives of the main groups, training according to the typical program for the special medical group conducted in the control groups did not significantly affect the indices of external respiration. After 24 weeks of training, the results of studies of the capacity of the bronchi of different diameter indicate that the use of normobaric - hypercapnic hypoxia in the classes positively influenced those speed indices of external respiration, which reflect the ability of the bronchi to pass air in the exhalation phase, (FVC, $\left.\mathrm{FVC}_{1} \mathrm{FEF}_{25} \mathrm{FEF}_{50} \mathrm{FEF}_{75}\right)$. The control group girls did not demonstrate any significant changes in these indices, according to a typical program of medical physical education for medical college students from NDC.

Conclusions. Generalization of scientific and methodological information indicates the annual dynamics of the prevalence of neurocirculatory dystonia among young people. The results of the study showed that the application of the proposed complex program, which includes therapeutic gymnastics, the method of creation in the body of normobaric hypercapnic hypoxia, morning hygienic gymnastics, simultaneous pouring cold water after a warm shower, self-massage of the collar zone and autogenous method of training contribute to the improvement of external and speed indices of external respiration.

Keywords: youth, physical rehabilitation, vegetative-vascular dystonia.

Постановка проблеми. Аналіз структури захворюваності показує, що серед студентів закладів вищої освіти (ЗВО) найбільш поширеною $\epsilon$ вегетосудинна, або нейроциркуляторна, дистонія (НЦД) [10, 11, 13].

Згідно з даними Т. В. Дьомкіної [4, 5], у Вінницькому медичному коледжі $32 \%$ студенток хворіють на НЦД, у той час як кількість хлопців з даним захворюванням становить 5,7 \%. Такий відсоток молоді з НЦД викликає занепокоєння, адже хвороба не лише обмежує фрізичну, емоційну і психологічну активність людини, але й негативно впливає на процес засвоєння навчального матеріалу [1].

Аналіз останніх досліджень і публікацій. Для покращення стану хворих на НЦД застосовують різноманітні засоби фрізичної реабілітації, які зменшують необхідність використання фрармакологічних препаратів тощо [8, 9, 14]. Широко застосовують лікувальну гімнастику (ЛГ), масаж, фізіотерапію, працетерапію тощо [3, 8-11]. Однак, як свідчать літературні джерела, такий спектр лікувальних засобів не завжди $\epsilon$ ефективним. Причому такі засоби фрізичної реабілітації застосовуються головним чином у диспансерних та санаторно-лікувальних закладах, що робить їх недоступними для молоді у період навчання через брак часу $[5,12,16,17] .3$ огляду на це постає проблема пошуку і розробки наближених до процесу навчання нових ефрективних технологій фрізичної реабілітації молоді, яка хворіє на НЦД. Тому, на наш погляд, доцільно ширше застосовувати методи створення в організмі стану нормобаричної гіперкапнічної гіпоксії [12, 15-17].

Існують також відомості про застосування дозованої гіпоксії для лікування осіб з гіпертоніч- ною хворобою. Тому перспективним напрямком вирішення проблеми лікування хворих на НЦД, головними симптомами якої $\epsilon$ підвищення або зниження артеріального тиску в умовах, наближених до навчального процесу, $є$ розробка і обгрунтування такої програми фрізичної реабілітації молоді, яка б включала не лише спеціальні фізичні вправи, а й методику створення в організмі стану нормобаричної гіперкапнічної гіпоксії, що й обумовило актуальність даного наукового дослідження.

Мета дослідження - науково-методично обгрунтувати та розробити програму фрізичної реабілітації із застосуванням методики створення в організмі стану нормобаричної гіперкапнічної гіпоксії для осіб молодого віку, хворих на НЦД.

\section{Завдання дослідження:}

- визначити і узагальнити сучасні науковометодичні відомості, результати вітчизняного i зарубіжного досвіду, що стосуються проблеми фрізичної реабілітації осіб молодого віку, хворих на НЦД.

- науково-методично обгрунтувати та розробити комплексну програму фрізичної реабілітації для осіб молодшого віку, хворих на НЦД.

- визначити ефективність впливу занять за розробленою комплексною програмою фрізичної реабілітації на показники зовнішнього дихання осіб молодого віку, хворих на НЦД за різними типами.

Методи i організація дослідження: теоретичний аналіз і узагальнення літературних джерел, електронна спірографрія 3 аналізом петлі «потік-об'єм», методи математичної статистики.

У дослідженні взяли участь студентки (61 особа) Вінницького медичного коледжу імені 
Д. К. Заболотного, у яких було діагностовано НЦД. Всі досліджувані були розподіленні на шість груп за типами НЦД. Три основні групи (ОГ, 10 осіб; ОГ, 11 осіб; ОГ, 9 осіб) та три контрольні (КГ, 9 осіб; КГ, 12 осіб; КГ, 10 осіб).

Досліджувані контрольних груп займалися за типовою програмою фрізичної реабілітації $[6,7]$ для спеціальних медичних груп на заняттях з фрізичного виховання (два рази на тиждень) та додатково один раз на тиждень у позанавчальний час під наглядом фрахівця з фрізичної реабілітації.

Досліджувані основних груп займалися за розробленою комплексною програмою з фізичної реабілітації, яка включала крім ЛГ методику створення в організмі стану нормобаричної гіперкапнічної гіпоксії, ранкову гігієнічну гімнастику (РГГ), одномоментне обливання холодною водою після теплого душу, вправи на фітболах, самомасаж, дозовані ходьбу і біг по біговій доріжці спортивного майданчика та аутогенне тренування за методикою Шульца. Заняття відбувалися два рази на тиждень під час проведення занять зі спеціальною медичною групою, згідно з розкладом з фрізичного виховання, і додатково один раз на тиждень під контролем викладача. Курс фрізичної реабілітації умовно було поділено на три періоди: вступний, основний та заключний. Тривалість усього курсу фрізичної реабілітації для осіб контрольних та основних груп становила 32 тиж.

Особливістю даної програми було те, що разом з наведеними вправами молодь з ВСД застосовувала методику створення в організмі стану нормобаричної гіперкапнічної гіпоксії. Для цього використовували апарат «Ендогенік 01» [2, 4]. Суть методики полягає у диханні пацієнта через апарат, де створюється додатковий опір за допомогою рідини, для проходження повітря у фазу вдиху та видиху, що викликає посилення роботи дихальних м'язів. При цьому порівняно з атмосферним повітрям досліджувані вдихали газову суміш з дещо меншим вмістом кисню і трохи більшим вуглекислого газу.

Механізм утворення газової суміші такий. Під час вдиху в аерозольній камері апарату відбувається розрідження, яке переміщує воду із зовнішньої камери у внутрішню. Атмосферне повітря, яке надходить через відкриті бокові отвори, потрапляє у зовнішню камеру, де через воду переходить в аерозольну камеру. У цій камері атмосфрерне повітря, що містить близько $21 \%$ кисню та 0,03 \% вуглекислого газу, перемішується з газовою сумішшю, що містить близько $16 \%$ кисню та $4 \%$ вуглекислого газу, яка залишилась після першого видиху. Таким чином у дихальний патрубок, а потім у легені потрапляє повітря, яке містить близько $18 \%$ кисню та $3 \%$ вуглекислого газу. Тобто вміст кисню в повітрі, що вдихається, зменшується в 1,1 раза, а вуглекислого газу - збільшується у 100 разів.

Таке співвідношення газів у апараті утримується протягом усієї процедури, що супроводжує виникнення в організмі помірної гіпоксії, яку можна класифрікувати як нормобаричну гіпоксичну гіперкапнічну при константних параметрах вмісту кисню та вуглекислого газу. Головною умовою під час дихання через апарат «Ендогенік 01» $€$ уповільнений, рівномірний видих. Тривалий видих супроводжує уповільнення дифузії вуглекислого газу із легень, за рахунок чого виникає стан помірної фрізіологічної гіпоксії та вираженої гіперкапнії. Водночас опір проходженню повітря під час видиху, створений поплавцем, сприяє механічному розширенню бронхів, яке після багаторазового повторення забезпечує підвищення їх пропускної спроможності. Механізм розширення бронхів у ході застосування процедури дихання через апарат пов'язаний також зі збільшенням внутрішньобронхіального тиску під час видиху. Водночас обмеження постачання організму киснем сприяє поступовому підвищенню ефективності легеневої вентиляції, збільшенню альвеолярної мережі капілярів легень та покращенню дифузії газів через альвеолярно-капілярний бар'єр, що сприяє зростанню оксигенації артеріальної крові. Під час занять на дихальному апараті активізується робота м'язів, які забезпечують черевний тип дихання (діафрагми та черевного преса). Також під час дихання збільшується кількість в крові еритроцитів, насичених 2,3-дифоосфогліцератом (2,3-ДФГ), що підвищує дисоціацію оксигемоглобіну $[12,16,17]$.

Результати дослідження. Як вказують літературні джерела, у осіб з НЦД знижена функція зовнішнього дихання. 3 огляду на це, ми визначали об'ємні і швидкісні показники зовнішнього дихання.

Заняття за розробленою програмою фрізичної реабілітації, яка включала методику створення в організмі стану нормобаричної гіперкапнічної гіпоксії, ранкову гігієнічну гімнастику, одномоментне обливання холодною водою після теплого душу, вправи на фрітболах, самомасаж, дозовані ходьбу і біг по біговій доріжці спортивного майданчика та аутогенне тренування за методикою Шульца викликали вірогідне покращення об'ємних і швидкісних показників зовнішнього дихання незалежно від типу захворювання в групах $\mathrm{O}_{1}, \mathrm{O \Gamma}_{2}$, $\mathrm{OГ}_{3}$, що підтверджено у таблицях 1-3.

На відміну від представниць основних груп заняття за типовою програмою спеціальних ме- 
ТАБЛИЦЯ 1 - Середнє значення показників зовнішнього дихання дівчат 17-19 років основної групи (ОГ $)$, хворих на нейроциркуляторну дистонію за кардіальним типом

\begin{tabular}{|c|c|c|c|c|c|c|c|c|c|c|}
\hline \multirow{3}{*}{$\begin{array}{l}\text { Показники } \\
\text { зовнішнього } \\
\text { дихання }\end{array}$} & \multicolumn{10}{|c|}{ Значення показників ( $n=10)$} \\
\hline & \multicolumn{2}{|c|}{$\begin{array}{c}\text { до початку } \\
\text { занять }\end{array}$} & \multicolumn{2}{|c|}{$\begin{array}{c}\text { через } 8 \\
\text { тиж. від початку } \\
\text { занять }\end{array}$} & \multicolumn{2}{|c|}{$\begin{array}{c}\text { через } 16 \\
\text { тиж. від } \\
\text { початку занять }\end{array}$} & \multicolumn{2}{|c|}{$\begin{array}{c}\text { через } 24 \\
\text { тиж. від початку } \\
\text { занять }\end{array}$} & \multicolumn{2}{|c|}{$\begin{array}{c}\text { через } 32 \\
\text { тиж. від початку } \\
\text { занять }\end{array}$} \\
\hline & $\overline{\mathbf{x}}$ & m & $\overline{\mathbf{x}}$ & m & $\overline{\mathbf{x}}$ & m & $\overline{\mathbf{x}}$ & m & $\overline{\mathbf{x}}$ & m \\
\hline \multicolumn{11}{|c|}{ Об’ємні показники } \\
\hline ЧД, разів & 19,2 & 0,37 & 19,0 & 0,38 & 18,8 & 0,36 & 18,0 & 0,34 & 18,1 & 0,32 \\
\hline ХОД, л·Хв ${ }^{-1}$ & 9,7 & 0,25 & 9,6 & 0,12 & 9,8 & 0,27 & 9,5 & 0,23 & 9,5 & 0,14 \\
\hline ДО, мл & 507 & 6,83 & 515 & 6,97 & 523 & 7,03 & $529^{*}$ & 7,11 & $532^{*}$ & 7,22 \\
\hline ЖЕЛ, мЛ & 2805 & 28,6 & 2859 & 28,5 & 2871 & 29,2 & $2891^{*}$ & 29,1 & $2908^{*}$ & 29,7 \\
\hline МВЛ, л & 68,79 & 1,78 & 70,7 & 1,83 & 72,3 & 1,92 & $73,87^{*}$ & 1,56 & $74,97^{*}$ & 1,73 \\
\hline \multicolumn{11}{|c|}{ Швидкісні показники } \\
\hline ФЖЄЛ, мл & 2152 & 29,65 & 2201 & 29,7 & 2218 & 29,9 & $2239^{*}$ & 30,01 & $2257^{*}$ & 30,07 \\
\hline ОФВ, мл & 1943 & 31,95 & 1993 & 32,1 & 2013 & 32,18 & $2045^{*}$ & 32,27 & $2058^{*}$ & 32,3 \\
\hline ОФВ & 0,74 & 0,007 & 0,74 & 0,009 & 0,74 & 0,008 & 0,75 & 0,009 & 0,75 & 0,01 \\
\hline ПОШ & 6,74 & 0,07 & 6,79 & 0,09 & 6,83 & 0,06 & $6,97^{*}$ & 0,08 & $7,01^{*}$ & 0,09 \\
\hline $\mathrm{MOШ}_{25}, \pi \cdot \mathrm{c}^{-1}$ & 6,32 & 0,09 & 6,47 & 0,07 & 6,49 & 0,08 & 6,54 & 0,09 & $6,57^{*}$ & 0,08 \\
\hline $\mathrm{MOШ}_{50}, \pi \cdot \mathrm{c}^{-1}$ & 4,7 & 0,07 & 4,79 & 0,08 & 4,83 & 0,08 & $4,94^{*}$ & 0,09 & $4,97^{*}$ & 0,09 \\
\hline $\mathrm{MOШ}_{75}, \pi \cdot \mathrm{c}^{-1}$ & 2,37 & 0,07 & 2,43 & 0,05 & 2,52 & 0,08 & $2,58^{*}$ & 0,07 & $2,59^{*}$ & 0,06 \\
\hline
\end{tabular}

${ }^{*} p<0,05$.

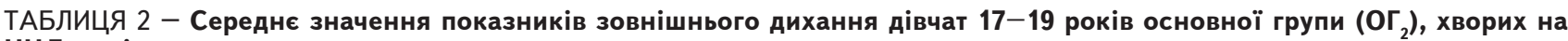
НЦД за гіпотензивним типом

\begin{tabular}{|c|c|c|c|c|c|c|c|c|c|c|}
\hline \multirow{3}{*}{$\begin{array}{l}\text { Показники } \\
\text { зовнішнього } \\
\text { дихання }\end{array}$} & \multicolumn{10}{|c|}{ Значення показників ( $\mathrm{n}=11)$} \\
\hline & \multicolumn{2}{|c|}{$\begin{array}{c}\text { до початку } \\
\text { занять }\end{array}$} & \multicolumn{2}{|c|}{$\begin{array}{c}\text { через } 8 \\
\text { тиж. від початку } \\
\text { занять }\end{array}$} & \multicolumn{2}{|c|}{$\begin{array}{c}\text { через } 16 \\
\text { тиж. від } \\
\text { початку занять }\end{array}$} & \multicolumn{2}{|c|}{$\begin{array}{l}\text { через } 24 \\
\text { тиж. від початку } \\
\text { занять }\end{array}$} & \multicolumn{2}{|c|}{$\begin{array}{c}\text { через } 32 \\
\text { тиж. від початку } \\
\text { занять }\end{array}$} \\
\hline & $\overline{\mathbf{x}}$ & m & $\overline{\mathbf{x}}$ & m & $\overline{\mathbf{x}}$ & m & $\overline{\mathbf{x}}$ & m & $\overline{\mathbf{x}}$ & m \\
\hline \multicolumn{11}{|c|}{ Об’ємні показники } \\
\hline ЧД, разів & 19,1 & 0,39 & 18,9 & 0,37 & 18,5 & 0,38 & 18,0 & 0,35 & 17,8 & 0,32 \\
\hline ХОД, л·Хв ${ }^{-1}$ & 9,5 & 0,32 & 9,3 & 0,30 & 9,1 & 0,31 & 9,3 & 0,29 & 9,3 & 0,30 \\
\hline ДО, мл & 500 & 7,25 & 513 & 7,26 & 516 & 7,30 & $522^{*}$ & 7,28 & $526^{*}$ & 7,31 \\
\hline ЖЕЛ, мл & 2806 & 29,7 & 2863 & 29,5 & 2877 & 29,1 & $2895^{\star}$ & 28,7 & $2910^{*}$ & 29,3 \\
\hline МВЛ, л & 68,62 & 1,65 & 71,15 & 1,71 & 72,57 & 1,63 & $73,97^{*}$ & 1,75 & $74,89^{*}$ & 1,8 \\
\hline \multicolumn{11}{|c|}{ Швидкісні показники } \\
\hline ФЖЄЛ, мл & 2156 & 29,69 & 2195 & 29,58 & 2209 & 29,68 & $2244^{*}$ & 30,0 & $2267^{* *}$ & 29,7 \\
\hline ОФВ, мл & 1943 & 31,84 & 1989 & 31,8 & 2024 & 31,9 & $2036^{*}$ & 31,88 & $2056^{\star *}$ & 31,92 \\
\hline ОФВ, /ЖЕЛ & 0,73 & 0,009 & 0,74 & 0,006 & 0,75 & 0,009 & 0,75 & 0,01 & 0,74 & 0,01 \\
\hline ПОШ & 6,71 & 0,07 & 6,85 & 0,06 & 6,87 & 0,09 & $6,95^{*}$ & 0,09 & $6,97^{*}$ & 0,08 \\
\hline $\mathrm{MOШ}_{25}, \pi \cdot \mathrm{c}^{-1}$ & 6,30 & 0,09 & 6,38 & 0,08 & 6,46 & 0,09 & $6,58^{*}$ & 0,08 & $6,62^{*}$ & 0,1 \\
\hline MOШ $_{50}, \pi \cdot \mathrm{c}^{-1}$ & 4,71 & 0,08 & 4,78 & 0,09 & 4,83 & 0,06 & $4,98^{*}$ & 0,09 & $5,01^{*}$ & 0,1 \\
\hline $\mathrm{MOШ}_{75}, \pi \cdot \mathrm{c}^{-1}$ & 2,35 & 0,03 & 2,37 & 0,02 & 2,41 & 0,04 & $2,47^{*}$ & 0,05 & $2,49^{*}$ & 0,04 \\
\hline
\end{tabular}

${ }^{*} p>0,05$.

дичних груп, які проводили в контрольних групах $\left(К \Gamma_{1}, К \Gamma_{2}, К \Gamma_{3}\right)$, суттєво не вплинули на показники зовнішнього дихання. Тоді як вірогідні зміни об'ємних і швидкісних показників спірографії у дівчат основних груп (ОГ $\left., 0 \Gamma_{2}, \mathrm{OГ}_{3}\right)$ зафріксовано через 24 тиж. від початку занять за розробленою програмою.
За даний період середнє значення показника частоти дихання і хвилинного об'єму дихання у дівчат, які хворіють на НЦД за кардіальним типом, вірогідно не змінилось. Через 32 тиж. дані показники залишилися на тому ж рівні. Подібні зміни показників ЧД і ХОД відбулися і у дівчат з гіпотензивним і гіпертензивним типами НЦД. 
ТАБЛИЦЯ 3 - Середнє значення показників зовнішнього дихання дівчат 17-19 років основної групи (ОГ $)$ ), хворих на нейроциркуляторну дистонію за гіпертензивним типом

\begin{tabular}{|c|c|c|c|c|c|c|c|c|c|c|}
\hline \multirow{3}{*}{$\begin{array}{l}\text { Показники } \\
\text { зовнішнього } \\
\text { дихання }\end{array}$} & \multicolumn{10}{|c|}{ Значення показників (n = 9) } \\
\hline & \multicolumn{2}{|c|}{$\begin{array}{c}\text { до початку } \\
\text { занять }\end{array}$} & \multicolumn{2}{|c|}{$\begin{array}{c}\text { через } 8 \\
\text { тиж. від початку } \\
\text { занять }\end{array}$} & \multicolumn{2}{|c|}{$\begin{array}{c}\text { через } 16 \\
\text { тиж. від } \\
\text { початку занять }\end{array}$} & \multicolumn{2}{|c|}{$\begin{array}{c}\text { через } 24 \\
\text { тиж. від початку } \\
\text { занять }\end{array}$} & \multicolumn{2}{|c|}{$\begin{array}{c}\text { через } 32 \\
\text { тиж. від початку } \\
\text { занять }\end{array}$} \\
\hline & $\overline{\mathbf{x}}$ & m & $\overline{\mathbf{x}}$ & $\mathbf{m}$ & $\overline{\mathbf{x}}$ & $\mathbf{m}$ & $\overline{\mathbf{x}}$ & $\mathbf{m}$ & $\overline{\mathbf{x}}$ & m \\
\hline \multicolumn{11}{|c|}{ Об’ємні показники } \\
\hline ЧД, разів & 19,3 & 0,4 & 18,8 & 0,37 & 18,7 & 0,4 & 18,1 & 0,36 & 17,9 & 0,32 \\
\hline ХОД, л·Хв & 9,7 & 0,23 & 9,5 & 0,22 & 9,2 & 0,25 & 9,4 & 0,26 & 9,4 & 0,23 \\
\hline ДО, мл & 502 & 7,3 & 510 & 7,33 & 515 & 7,32 & $524^{*}$ & 7,36 & $528^{*}$ & 7,37 \\
\hline ЖєЛ, мл & 2807 & 29,2 & 2838 & 29,7 & 2867 & 28,9 & $2906^{*}$ & 29,3 & $2915^{*}$ & 29,4 \\
\hline МВЛ, л & 67,98 & 1,71 & 70,91 & 1,86 & 71,75 & 1,56 & $73,5^{\star}$ & 1,74 & $73,94^{*}$ & 1,68 \\
\hline \multicolumn{11}{|c|}{ Швидкісні показники } \\
\hline ФЖЕЛ, мл & 2152 & 28,9 & 2188 & 29,11 & 2213 & 29,08 & $2237^{*}$ & 29,1 & $2256^{*}$ & 29,12 \\
\hline ОФВ & 1940 & 31,78 & 1967 & 31,96 & 2022 & 31,81 & $2039^{*}$ & 32,08 & $2053^{*}$ & 32,1 \\
\hline ОФВ,ЖЖЕЛ & 0,75 & 0,006 & 0,75 & 0,005 & 0,74 & 0,007 & 0,77 & 0,008 & 0,76 & 0,007 \\
\hline ПОШ & 6,72 & 0,04 & 6,77 & 0,06 & 6,8 & 0,05 & 6,82 & 0,08 & $6,93^{*}$ & 0,09 \\
\hline $\mathrm{MOШ}_{25}, \pi \cdot \mathrm{c}^{-1}$ & 6,31 & 0,08 & 6,42 & 0,09 & 6,47 & 0,1 & 6,46 & 0,11 & $6,58^{*}$ & 0,09 \\
\hline $\mathrm{MOШ}_{50}, \pi \cdot \mathrm{c}^{-1}$ & 4,72 & 0,07 & 4,78 & 0,06 & 4,81 & 0,09 & $4,89^{*}$ & 0,1 & $4,98^{*}$ & 0,09 \\
\hline $\mathrm{MOШ}_{75}, \pi \cdot \mathrm{c}^{-1}$ & 2,36 & 0,04 & 2,41 & 0,05 & 2,47 & 0,04 & $2,51^{*}$ & 0,05 & $2,54^{*}$ & 0,06 \\
\hline
\end{tabular}

${ }^{*} p>0,05$

Середня величина життєвої ємності легень (ЖЄЛ), яка відображає функціональні можливості дихальних м'язів, протягом 32-тижневого циклу занять у контрольних групах суттєво не змінилась. Разом з тим у дівчат усіх основних груп середня величина даного показника вірогідно зросла. Через 24 тиж. середнє значення показника ЖЕЛ у дівчат з кардіальним типом вірогідно збільшилось на 2,97 \% ( $<<0,05)$, а через 32 тиж. - на $3,54 \%$ (р <0,05).

Подібні зміни показника ЖЄЛ зареєстровано у дівчат групи з гіпотензивним та гіпертензивним типами НЦД. По завершенні 24-тижневого періоду занять у студенток з гіпотензивним типом ЖЕЛ зросла на $3,07 \%(p<0,05)$, а через 32 тиж. на $3,57 \%(p<0,05)$. У дівчат з гіпертензивним типом через 24 тиж. ЖЕЛ підвищилась порівняно з вихідним рівнем на $3,41 \%(p<0,05)$, а через 32 тиж. - на 3,7\% (р <0,05).

Застосування методики створення в організмі стану нормобаричної гіперкапнічної гіпоксії в комплексі з іншими засобами фрізичної реабілітації сприяло зростанню показника максимальної вентиляції легень (МВЛ). У представниць з кардіальним типом через 24 тиж. від початку занять даний показник підвищився на $6,88 \%$ ( $<<0,05)$, а через 32 тиж. - на 8,24\% ( $<<0,05)$, у дівчат 3 гіпотензивним типом захворювання відповідно на $7,23 \%$ ( $<<0,05)$, а через 32 тиж. - на 8,37 \%
( $p<0,05)$. У дівчат з гіпертензивним типом через 24 тиж. показник МВЛ збільшився на 7,51\% (р < $<0,05)$, а через 32 тиж. - на 8,06\% ( $<<0,05)$.

Результати досліджень пропускної спроможності бронхів різного діаметра свідчать про те, що застосування методики нормобаричної гіперкапнічної гіпоксії позитивно відобразилось на таких швидкісних показниках зовнішнього дихання, як ФЖЄЛ, ОФВ, , ПОШ У дівчат контрольної групи заняття за типовою програмою з лікувальної фрізичної культури для студенток медичного коледжу, які хворіють на НЦД, не викликали вірогідних змін вищезгаданих показників.

На відміну від дівчат контрольної групи, у студенток усіх трьох основних груп відбулося вірогідне зростання даних показників через 24 тиж. від початку занять. Середнє значення показника форсованої життєвої ємності легень (ФЖЕЛ) у дівчат з кардіальним типом за цей період вірогідно збільшилось на 3,89\% ( $<<0,05)$, 3 гіпотензивним типом - на 3,92\% ( $<<0,05)$, а 3 гіпертензивним - на 3,8\% (p<0,05). Через 32 тиж. занять середня величина показника ФЖЄЛ вірогідно покращилась у дівчат групи ОГ (з кардіальним типом НЦД) на 4,65 \% (р < $0,05)$, групи ОГ 2 (з гіпотензивним типом НЦД) на $4,9 \%(p<0,05)$ і групи ОГ 3 (з гіпертензивним типом НЦД) - на $4,61 \%(p<0,05)$. 
Свідченням позитивного впливу занять на здатність бронхів пропускати повітря у фразу видиху є зростання середньої величини об'єму форсованого видиху за першу секунду $\left(О Ф \mathrm{~B}_{1}\right)$ у представниць усіх основних груп (ОГ $\left., 0 \Gamma_{2}, \mathrm{OГ}_{3}\right)$. У дівчат групи ОГ (з кардіальним типом НЦД) середнє значення ОФВ чатку занять зросло на $5,0 \%$ (p $<0,05)$, групи $\mathrm{OГ}_{2}$ (з гіпотензивним типом НЦД) - на 4,57\% (p $<0,05)$, а групи ОГ 3 (з гіпертензивним типом НЦД) - на 4,86\% ( $<<0,05)$. Протягом наступних 8 тиж. занять за розробленою програмою середні значення дещо збільшились (близько $1 \%)$, однак таке зростання не слід вважати суттєвим тому, що через 32 тиж. вони вірогідно не відрізнялись порівняно з тими, що були зареєстровані через 8 тиж.

Показник об'єму форсованого видиху за першу секунду по відношенню до життєвої ємності легень (ОФВ ${ }_{1} /$ ЖЛЛ) протягом усього 32-тижневого періоду занять залишився незмінним в усіх трьох основних групах.

Середнє значення показника пікової об'ємної

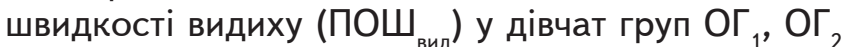
вірогідно підвищилося через 24 тиж. від початку занять відповідно на 3,3 і 3,45 \%, несуттєво змінюючись протягом наступних 8 тиж. занять. У дівчат групи ОГ 3 вірогідне зростання даного показника зареєстровано через 32 тиж. від початку занять за розробленою програмою - на 3,03 \% $(p<0,05)$.

Зростання таких показників, як ФЖЄЛ, ОФВ, ПОШ у у представниць усіх трьох основних груп свідчить не лише про підвищення фрункціональних можливостей дихальних м'язів, а також про зменшення тонусу гладеньких м'язів крупних бронхів.

Середні значення показника миттєвої об'ємної швидкості проходження повітря на ділянці

\section{Література}

1. Гаврилова Н, Онищук В. Оцінка психічного та функціонального станів студенток, хворих на нейроциркуляторну дистонію [Assessment of mental and functional state of students with neurocirculatory dystonia]. Фізична культура, спорт та здоров'я нації. 2019; 7 (26): 249-55.

2. Галандзовський С. Покращення показників дихальної спірографії у студентів транспортного коледжу шляхом використання бігових навантажень та методики «ендогенно-гіпоксичного» дихання [Improving respiratory spirography in transport college students through the use of running loads and methods of "endogenous-hypoxic" breathing]. Фізичне виховання, спорт і культура здоров'я у сучасному суспільстві: зб. наук. праць Східноєвропейського національного університету імені Лесі Українки. Луцьк, 2017; 2 (38): 64-9

3. Долгієр ЄВ. Фізична реабілітація жінок ювенільного періоду, хворих на нейроциркуляторну дистонію, засобами оздоровчої аеробіки [Physical rehabilitation of women of the juvenile period, patients with крупних бронхів (МОШ ${ }_{25}$ ) у студенток груп ОГ і ОГ 3 порівняно зі значеннями, які зареєстровані до початку формувального експерименту, через 32 тиж. зросли відповідно на 3,81 та 4,1\% ( $p<0,05)$. У дівчат групи ОГ 2 середнє значення даного показника вірогідно зросло дещо раніше - через 24 тиж. від початку занять на 4,26 \%, суттєво не змінюючись протягом наступних 8 тиж. занять. Такі зміни показника МОШ підтверджують зменшення тонусу гладеньких м'язів крупних бронхів у процесі занять за програмою.

Під впливом занять за розробленою програмою покращення відбулися не лише в бронхах великого діаметра, але й середнього і дрібного, про що свідчить вірогідне збільшення середніх величин показників МОШ ${ }_{50}$, МОШ $_{75}$ в групах ОГ $\mathrm{O \Gamma}_{2}, \mathrm{OГ}$

Отже, застосування комплексної програми фрізичної реабілітації дівчат 17-19 років з НЦД за різними типами, яка включала методику створення в організмі стану нормобаричної гіперкапнічної гіпоксії, сприяло покращенню фрункції зовнішнього дихання за об'ємними й швидкісними показниками спірографіï.

\section{Висновки}

1. Узагальнення науково-методичної інфрормації свідчить про щорічну динаміку зростання НЦД серед дівчат молодого віку.

2. Результати дослідження показали, що застосування запропонованої комплексної програми, яка включає ЛГ, методику створення в організмі стану нормобаричної гіперкапнічної гіпоксії, РГГ, одномоментне обливання холодною водою після теплого душу, самомасаж комірцевої зони та аутогенне тренування за методикою Шульца, сприяє покращенню середніх величин об'ємних і швидкісних показників зовнішнього дихання.

neurocirculatory dystonia by means of health aerobics] [Автореферат]. Київ 2013. 21 C.

4. Дьомкіна ТВ, Онищук ВЄ. Експрес-вплив ендогенно-гіоксичного дихання на показники артеріального тиску та спірографії студенток, хворих на нейроциркуляторну дистонію [Express effect of endogenoushyoxic respiration on blood pressure and spirography of female students with neurocirculatory dystonia]. Фізичне виховання, спорт і культура здоров'я у сучасному суспільстві: зб. наук. праць Східноєвропейського національного університету імені Лесі Українки. Луцьк, 2015; 2 (30): 114-8.

5. Дьомкіна ТВ, Онищук ВЄ. Перспективи застосування нормобаричної гіперкапнічної гіпоксії в системі фрізичної реабілітації студенток медичного коледжу, хворих нейроциркуляторною дистонією [Prospects of using normobaric hypercapnic hypoxia in the system of physical rehabilitation of medical college students with neurocirculatory dystonia] Фізична культура, спорт та здоров'я нації: зб. наук. праць. Вінниця, 2015; 19, Т. 1 : 590-4. 
6. Методичні рекомендації «Вегетосудинна дистонія» для студентів і викладачів спеціальної медичної групи і ЛФК, спеціалістів з фізичної реабілітації [Methodical recommendations "Vegetative-vascular dystonia" for students and teachers of special medical group and exercise therapy, specialists in physical rehabilitation]. Укладачі Репневська МС, Капацина ТВ. Донецьк: ДонНТУ; 2014. 62 с.

7. Мордвінова АВ, Бурла ОЙ. Програма фізичного виховання студентів спеціальних медичних груп хворих на вегетосудинну дистонію [Physical education program for students of special medical groups of patients with vegetative-vascular dystonia]. Молода спортивна наука України. 2011; 2: 169-75.

8. Мухін ВМ. Фізична реабілітація [Physical rehabilitation ]: [підручник], [2-е вид.], перероб. та доп. К.: Олімпійська література; 2005. 470 с.

9. Назар ПС, Шахліна ЛГ. Загальний та спеціальний догляд за хворими з елементами фізичної реабілітації [General and special care for patients with elements of physical rehabilitation] [навч. посібник]. Київ: Олімпійська література; 2006. 240 c

10. Ніколенко О. Теоретичні основи застосування засобів фізичної реабілітації хворим на вегето-судинну дистонію [Theoretical bases of application of means of physical rehabilitation to patients with vegetativevascular dystonia]. Вісник Прикарпатського університету. Фізична культуpa. 2018; 29: 53-6.

11. Ольховик АВ. Фізична реабілітація студентів спеціальної медичної групи із захворюванням на вегето-судинну дистонію за змішаним типом [Physical rehabilitation of students of a special medical group with a disease of vegetative-vascular dystonia of mixed type] [автореферат]. Київ, 2015. 20 c.

furman-dok@ukr.net
12. Онищук ВЄ. Застосування ендогенно-гіпоксичного дихання в системі реабілітації студентів з бронхіальною астмою [The use of endogenous-hypoxic respiration in the rehabilitation system of students with bronchial asthma] [авторесрерат]. Київ, 2012. 21 c.

13. Репнєвська МС, Репнєвська МС, Капацина ТВ, Кучер ГП. Методи і засоби фізичної реабілітації для студентів спеціальної медичної групи ВНЗ при вегетосудинній дистонії (ВСД) [Methods and means of physica rehabilitation for students of the special medical group of the university for vascular dystonia (VD)]. Актуальні питання освіти, спорту та здоров'я у вищих навчальних закладах. Донецьк: ДонДУУ. 2014; 108-14.

14. Физическая реабилитация [Physical rehabilitation]. Попова СП редактор. Р-н-Д: Феникс; 2007. 608

15. Фурман ЮМ, Онищук ВЄ. Ефективність застосування методики «ендогенно-гіпоксичного» дихання за показниками спірографрії в системі фрізичної реабілітації студенток, хворих на бронхіальну астму [The effectiveness of the method of "endogenous-hypoxic" breathing on the indicators of spirography in the system of physical rehabilitation of female students with asthma ]. Фізична культура, спорт та здоров'я нації. 2010, 10: 101-7.

16. Фурман ЮМ, Онищук В€. Комплексне застосування методики «ендогенно-гіпоксичного» дихання в реабілітації студентів, хворих на бронхіальну астму\{ Complex application of the technique of "endogenoushypoxic" respiration in the rehabilitation of students with bronchial asthma\}. Спортивна медицина. 2011; 1-2; 120-5.

17. Onyshuk V. Substantiation of the integrated physical rehabilitation program for higher education establishments students suffering from bronchial asthma Journal of Physical Education and Sport (JPES). 2017; 4 17, Art 290: 2561-67.

Надійшла 21.04.2020 